\title{
DIFFERENTIATION OF INCOME DISTRIBUTION OF FARMERS' HOUSEHOLDS IN THE POLISH MACRO-REGIONS
}

\author{
ALINA JECDRZEJCZAK \\ DOROTA PEKASIEWICZ
}

\begin{abstract}
Income distribution analysis can be conducted from the point of view of the comparisons between different geographical regions, family types or socio-economic groups it can also be carried out to assess the effects of an economic policy over time. The paper presents the results of a research on income distribution of Polish farmers which allowed us to formulate several conclusions concerning the differentiation of income inequality, poverty and wealth for the households of farmers in different macro-regions. The analysis uses the Gini inequality index and selected poverty and wealth indicators. The basis for the calculations was micro data coming from the Household Budget Survey conducted by the Central Statistical Office of Poland for 2015. The results of the research showed that the highest income inequality among the farmers' households was observed in the northern region. Also this region was characterised by the highest percentage of households considered affluent. But the lowest Gini inequality coefficient was observed for the south-western region, where there were no farmers' households exceeding the richness threshold.
\end{abstract}

Keywords: farmers' household, region, income inequality, poverty, wealth.

JEL codes: C13, C16, D31, Q19 


\section{Introduction}

It is well-known that high income inequality can have several undesirable political and social consequences, such as poverty and polarization of particular economic groups and regions. The high level of income inequality is also contradictory to the social components of the idea of sustainable development that has been initiated through the Lisbon Strategy and continued by the Sustainable Development Strategy and the Europe 2020 strategy. It can be seen that among the most developed countries in agriculture, the highest level of sustainability of development is observed where the level of income inequality is relatively low (see Kryszak, 2016).

The regional diversification of Poland has been maintained since the $19^{\text {th }}$ century, when three different economic systems developed on its lands (Kukuła (ed.), 2010). The diversity was influenced by the diversity of natural, organisational, economic and environmental conditions (Kopiński and Matyka, 2016). The specificity of farmers' income distribution in particular regions is closely related to the socalled agricultural culture resulting, for instance, from different area structures of farms, soil quality, climate, and technical advancement. Currently, organisational and economic factors seem to have a greater impact on territorial differentiation of agricultural production than natural conditions. The voivodeships in which agriculture achieves high economic effects include the Wielkopolskie from the northwestern macro-region and the Kujawsko-Pomorskie from the northern macro-region. In these regions, structural changes and adjustment processes leading to the concentration and specialization of agricultural production are carried out faster and more efficiently than in other parts of the country (Michna, 2005). The number of large-scale farms may also have a significant impact on the distribution of income and its inequality. The region characterized by a large number of such farms is the north-western macro-region, in contrast to the central and southern regions.

Income distribution of a population of households or groups of households distinguished by region, socio-economic group or family type are of special interest to economists and statisticians. A statistical analysis of income inequality among the households of farmers in Poland was carried out by Jędrzejczak and Pekasiewicz (2017) and covered the period between 2006 and 2014. The findings obtained by the Authors of the paper revealed high level of poverty incidence for this group of households in all the years under consideration (from $25.55 \%$ to $28.18 \%$,). Simultaneously, the farmers' households were characterised by the highest share of very high incomes, i.e. equivalent incomes above a predefined wealth threshold (from $6.62 \%$ to $9.75 \%$ ). This phenomenon was confirmed by very high values of income inequality indexes as the Gini and Zenga coefficients were $\mathrm{G}=0.475$ and $\mathrm{Z}=0.586$, respectively. Moreover, extremely high discrepancy has been detected between the extremal parts of the distribution.

The specificity of economic activity that is agriculture allows us to assume that the income distribution of farmers' households is closely related to regions of Poland. Therefore, the objective of this paper was to analyse income inequality of farmers by six macro-regions (NUTS1): central, southern, eastern, north-western, 
south-western and northern. For the analysis, statistical measures of inequality, poverty and wealth were applied, which are presented, e.g. in the works of Jędrzejczak (2011), Kot (2008), Silber (1999). This analysis helped us to reveal the degree of economic inequality within particular macro-regions as well as to observe discrepancies between them in the year 2015 .

The analysis focused on household available income, which is a basic income category within the Household Budget Survey. According to GUS (2016, pp. 18-19): "household's available income is defined as a sum of household's current incomes from various sources reduced by prepayments on personal income tax made on behalf of a tax payer by tax-remitter (this is the case with income from hired work and social security benefits and other social benefits) by tax on income from property, taxes paid by self-employed persons, including those in free professions and individual farmers and by social security and health insurance premiums. The available income covers both income in cash and in kind, including natural consumption (consumer goods and services taken to satisfy household's needs from self-employment - in and outside farming) as well as goods and services received free of charge. Available income is allocated to expenditures and savings increase". To account for the influence of different household sizes on the results of the inequality and poverty analysis, for each household its available income has been converted into equivalent income. Equivalence scales are making it possible to compare material situation of households differing in size and demographic structure - in the study the new OECD scale was applied.

The first section is devoted to the presentation of selected statistical methods of income distribution and income inequality analysis, which will be used in further parts of the work. In the second section, the distribution of farmers' household income is compared with the distributions observed in other socio-economic groups. The next paragraph is devoted to the analysis of territorial differentiation of income distribution in the group of farmers' households. Both measures of income inequality as well as levels of poverty and wealth, poverty risk, intensity and depth in particular regions of Poland were taken into account. To assess income inequality the Gini coefficient was used, while in the poverty analysis, among others, at-risk-of-poverty rate and poverty gap indexes were applied. The basis of the calculations was the micro-data on household incomes derived from the Household Budget Survey conducted by the Central Statistical Office (pl. Główny Urząd Statystyczny, GUS) in 2015

\section{Research methodology}

Income inequality refers to the degree of difference in earnings among various individuals or segments of a population. Measures of inequality, also called concentration coefficients, are widely used to study income, welfare and poverty issues. Amongst numerous inequality measures the Gini (1912) and Zenga (1990, 2007) coefficients are of the greatest importance. The Gini concentration coefficient is the most widely used measure of income inequality, mainly because of its clear economic interpretation. 
The Gini inequality index, based on the well-known Lorenz curve, can be expressed as follows:

$$
G=2 \int_{0}^{1}(p-L(p)) d p
$$

where: $p=F(y)$ and $F$ is a cumulative distribution function of income, $L(p)$ is the Lorenz function given by the following formula:

$$
L(p)=\mu^{-1} \int_{0}^{p} F^{-1}(t) d t
$$

where: $\mu$ denotes the expected value of a random variable $Y$, and $F^{-1}$ is the inverse cumulative distribution function $F$.

The formulas given above can be applied under the assumption that a theoretical probability distribution describing empirical income data is well known In practice, inequality coefficients, including the Gini index, are usually estimated from empirical data coming from representative samples.

One can estimate the value of the Gini index from the survey data using the following formula:(3), proposed by Fei, Ranis and Kuo (1978):

$$
\widehat{G}=\frac{2 \sum_{i=1}^{n}\left(w_{i} y_{(i)} \sum_{j=1}^{i} w_{j}\right)-\sum_{i=1}^{n} w_{i} y_{(i)}}{\left(\sum_{i=1}^{n} w_{i}\right) \sum_{i=1}^{n} w_{i} y_{(i)}}-1
$$

where: $y_{(i)}$ - household incomes in a non-descending order, $w_{i}$ - survey weight for agą $i$-tej jednostki natomiast $\sum_{j=1}^{i} w_{j}-$ rank of $i$-th economic unit in $n$-element sample.

Formula (3) can be applied for individual data coming from random samples, e.g. samples obtained within the Household Budget Survey, as it incorporates survey weights available for each statistical unit and constructed on the basis of their inclusion probabilities. These weights make it possible to adjust for unequal selection probabilities and non-response bias.

A popular inequality measure based on income shares received by subsequent decile groups is the coefficient of maximum equalisation, also known as the Schutz index or the Pietra ratio:

$$
\widehat{E}=\sum_{j \in I} 100\left(S_{j}-0,1\right)
$$

for: $I=\{1,2, \ldots, 10\}, S_{j}>0.1$ and $S_{j}=\frac{\sum_{i \in G D_{j}} w_{i} y_{i}}{\sum_{i=1}^{n} w_{i} y_{i}}$, where $S_{j}$ is income share of the $j$-th decile group $G D_{j}$ in the total income of all the households under consideration.

The coefficient of maximum equalisation given by (4) can be interpreted as the portion of the total income that would have to be redistributed, taken from the 
decile groups having more than $10 \%$ of the total income of the population and given to the poorer decile groups, that is the groups having the shares in total income smaller than $10 \%$, for there to be income equality.

During a thorough income distribution analysis the problem of inequality measurement is usually interrelated with the estimation of poverty and (not so often) wealth indices for the population groups. Starting with the publication of Sen (1976) seminal paper, numerous poverty measures have been proposed and analysed but in practice the most popular are poverty indexes belonging to the FGT class (Foster-Greer-Thorbecke), which comprises three basic aspects of this phenomenon: incidence, depth and severity (see Panek, 2011). The most popular poverty index is undoubtfully at-risk-of-poverty rate also called poverty head-count ratio:

$$
W_{p}=\frac{n_{p}}{n}
$$

where: $n_{p}$ is number of poor individuals or households (with income below the poverty line) while $n$ denotes the number of all income receivers. It determines the share of households whose equivalent income (or consumption) is below a poverty threshold.

The poverty threshold is usually assumed as $60 \%$ of national median equivalent income - this approach is used in EU-SILC, the European Union Statistics on Income and Living Conditions, anchored by Eurostat. In some publications of the Central Statistical Office of Poland one can find another relative poverty line $-50 \%$ of mean equivalent income. In this study we utilize the Eurostat poverty threshold equal to $y_{p}^{*}=0.6 \mathrm{Me}$, where $\mathrm{Me}$ denotes median of the equivalent household income in Poland.

ine head-count index (5) can be estimated from the $n$-element sample data by means of the following formula:

$$
\widehat{W}_{p}=\frac{\sum_{i=1}^{n} I_{i} w_{i}}{\sum_{i=1}^{n} w_{i}}
$$

where: $I_{i}$ - indicator function taking value 1 when $i$-th household equivalent income is below a poverty line, and taking value 0 in the opposite situation, $w_{i}-$ survey weight for $i$-th economic unit.

Poverty gap index provides information regarding the distance of households from the poverty line. This measure captures the mean aggregate income or consumption shortfall relative to the poverty line across the whole population. It is obtained by adding up all the shortfalls of the poor and dividing the total by the population size:

$$
P G=\frac{1}{n} \sum_{i=1}^{n_{p}} \frac{y_{p}^{*}-y_{i}}{y_{p}^{*}}
$$

where: $y_{i}$ is household equivalent income, $y_{p}^{*}$ denotes the poverty line (poverty threshold), $n_{p}$ is the number of poor households, $n$ - population (or subpopulation) size. By replacing the number of households $n$ by the number of the poor $n_{p}$ in the formula (7), we obtain an alternative poverty gap index: 


$$
P G_{p}=\frac{1}{n_{p}} \sum_{i=1}^{n_{p}} \frac{y_{p}^{*}-y_{i}}{y_{p}^{*}}
$$

It can be shown that: $P G=P G_{p} \cdot W_{p}$.

The estimators of poverty gap indexes given by (7) and (8), which incorporate sampling weights $w_{i}$, are the following:

and

$$
\widehat{P G}=\frac{\sum_{i=1}^{n_{p}}\left(\left(y_{p}^{*}-y_{i}\right) / y_{p}^{*}\right) w_{i}}{\sum_{i=1}^{n} w_{i}}
$$

$$
\widehat{P G}_{p}=\frac{\sum_{i=1}^{n_{p}}\left(\left(y_{p}^{*}-y_{i}\right) / y_{p}^{*}\right) w_{i}}{\sum_{i=1}^{n_{p}} w_{i}}
$$

The indexes (8) and (10) can be interpreted as minimum income that should have been transferred from the rich to the poor households to totally cancel poverty.

Poverty severity index (squared poverty gap) takes into account not only the distance separating the poor from the poverty line (the poverty gap), but also the inequality among the poor. It takes the form:

$$
P S_{p}=\frac{1}{n_{p}} \sum_{i=1}^{n_{p}}\left(\frac{y_{p}^{*}-y_{i}}{y_{p}^{*}}\right)^{2}
$$

In the poverty severity index higher weights are placed on those households which are further away from the poverty line. To estimate the index (11) from the sample data we utilize the approach similar to that applied in the case of the poverty gap index, after squaring each poverty gap data (see: eq. (10)).

In the analysis of population wealth, a popular measure is the wealth incidence index, based on the share of the households whose equivalent income (or consumption) is above a wealth threshold, which can be established in many different ways e.g. as triple equivalent median income . It can be expressed by the following expression:

$$
W_{r}=\frac{n_{r}}{n}
$$

where: $n_{r}$ - is number of rich individuals or households (receiving income above a wealth threshold), $n$-denotes the number of all income receivers.

Using the idea of the poverty gap we can also determine the wealth gap that can be considered a measure of wealth depth. This measure should be based on the distances of all the rich households between their income and an arbitrary wealth threshold: 


$$
\widehat{R G}_{r}=\frac{\sum_{i=1}^{n_{r}}\left(\left(y_{i}-y_{r}^{*}\right) / y_{r}^{*}\right) w_{i}}{\sum_{i=1}^{n_{r}} w_{i}}
$$

where: $y_{r}^{*}$ denotes the wealth threshold.

Other examples of statistical characteristics applied in the measurement of poverty and social exclusion can be found e.g. in Rusnak (2011) and Panek (2011).

\section{Comparative analysis of income distribution of farmers with the other socio-economic groups}

The empirical analysis presented in the paper was based on the data from the random sample obtained within the Household Budget Survey conducted by the Central Statistical Office of Poland in 2015. The research is focused on the material situation of the farmers' households, which are defined as "households whose exclusive or main (prevailing) source of maintenance is income from the use of private farm in agriculture. Additional sources of maintenance for this group of households may include old age pension, other types of pension or any other unearned income, hired work, self-employment or free profession. The income gained from additional sources is lower than that from the private farm in agriculture" (GUS, 2016, p. 29). For the calculations the study used the so-called micro or individual data, i.e. information at the level of individual respondents (households).

The Household Budget Survey (HBS) plays an important role in the analysis of the living standards of the Polish population. It is the basic source of information on the revenues, outgoings, quantitative food consumption and other aspects of the living conditions of particular groups of the population. The data obtained from this survey allow for the analysis of different factors influencing income distribution and its inequality. HBS is based on the representative method which allows for the generalisation of the results to the whole population of households within a margin of an error. In the Household Budget the survey unit is a one-person or multi-person household. In 2015, the randomly selected sample covered 37148 households, i.e. approximately $0.3 \%$ of the total number of households in Poland.

The adopted sampling design was a geographically stratified and two-stage one with different selection probability at the first stage. The sampling units for the first stage (primary sampling units, psu) were the area survey points (asp), and those for the second stage (secondary sampling units, ssu) - were dwellings. The first stage sampling frame was based on the records of statistical areas (sets of areas) designed for the National Census purposes and updated annually by the changes resulting from the administrative division of the country as well as construction of new and dismantle of old houses.

Prior to sample selection, the asp were stratified separately for every voivodeship by 6 classes of locality. Big cities usually constituted separate strata. In small cities and rural areas the strata were composed of groups of asp comprising neighbouring, partly rural poviats (by NTS3 nomenclature). In total, 191 strata were 
created, out of which 58 were located in rural areas. Primary sampling units were selected separately from each strata by means of the systematic sampling from randomly permutated units ( i.e. Hartley-Rao scheme). In 2015, two subsamples, consisting of 783 asp each, were used. The monthly rotation of households implemented since 1993 assumes that every month of the year a different group of households participates in the survey.

It was assumed that each dwelling (household) should have the same sampling probability what is known as the self-weighting sampling design. That is why sample of 675 asp was divided approximately in proportion to the number of dwellings in the strata. Simultaneously, primary sampling units were selected with probabilities proportional to their sizes assumed as the numbers of dwellings in each asp. At the second stage, the constant number of 24 ssu from each psu were selected.

What is especially important from the point of view of this research, starting from 2005 the number of asp in rural areas were increased by $50 \%$ for the more precise results concerning farmers' households. Additionally, the sample of 108 rural asp was drawn and divided in proportion to the number of dwellings in rural strata. Because of non-participation of a part of households there is a difference between the structure of the surveyed sample and that of the selected one revealed by the socio-demographic traits. Therefore, the survey results were weighted with the use of the 2011 National Census data, broken down by the number of persons in households and place of residence (urban and rural areas). In the HBS data set, besides the basic categories of income and expenditures of households, there are the sampling weights that were used in this study to generalise from the sample to the whole population.

At the first step, the comparative analysis of income distribution of farmers with respect to the other socio-economic groups were carried out.

It is worth noting that income and wage distributions are usually unimodal, positively asymmetrical and present high kurtosis, i.e they tend to have heavy tails relative to the normal distribution. The Dagum model, belonging to the class of Burrtype-III curves, is considered one of the best theoretical distributions to describe income size distributions in different divisions (Kleiber and Kotz, 2003).

The results of the approximation of income distributions in Poland by means of the Dagum model, for each of five socio-economic groups and for the whole country, are presented in Figure 1. High values of the coefficients of distributions similarity (also called the overlap measure, which is based on the comparison between empirical and theoretical frequencies for all income intervals), reveal satisfactory goodness of fit for all the distributions under consideration. 


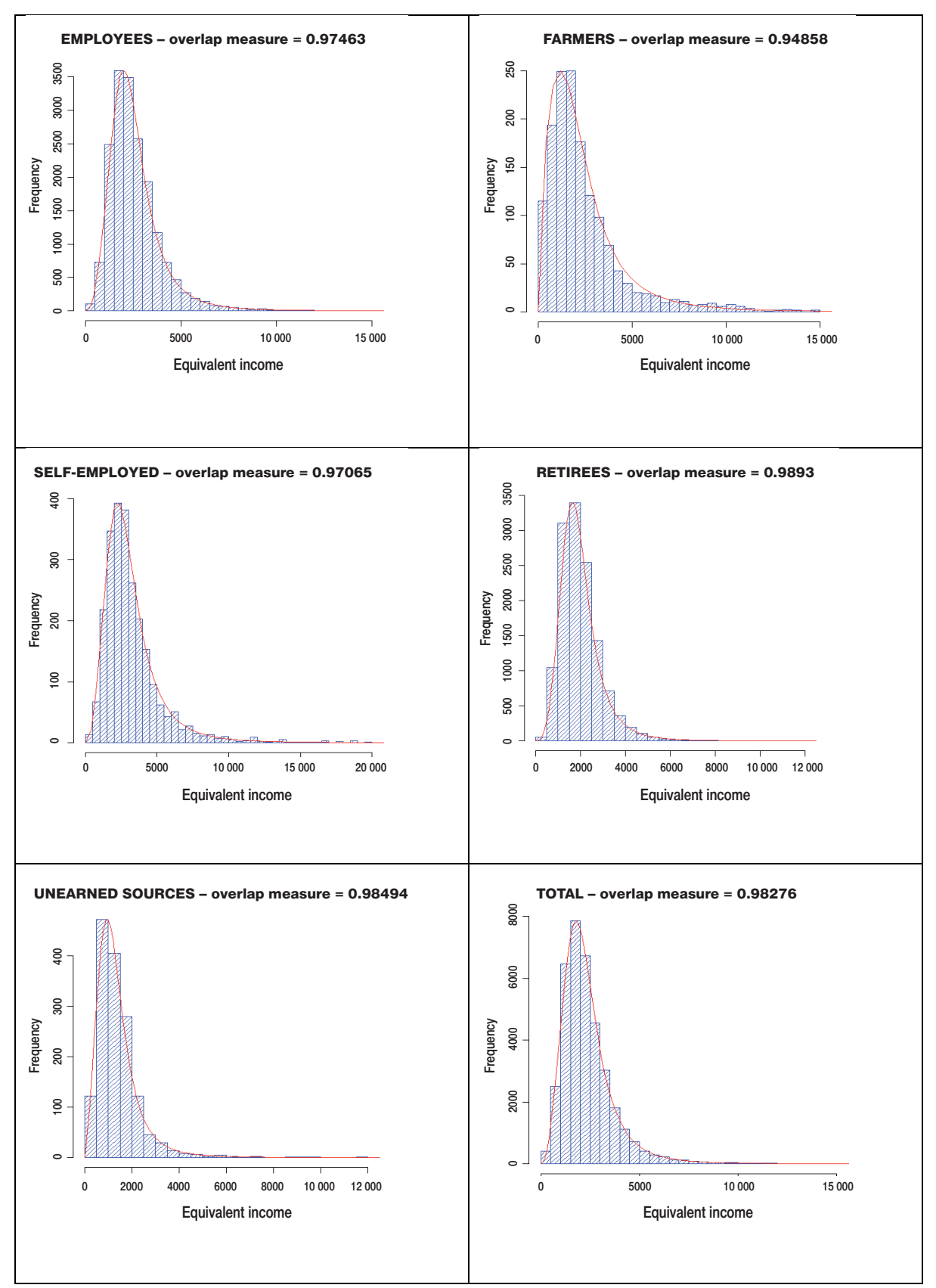

Fig. 1. Distribution of equivalent income for socio-economic groups in 2015 and their approximation by means of the Dagum type-I model.

Source: own elaboration. 
Table 1

Statistical characteristics of equivalent income distributions in Poland in 2015 by socio-economic group

\begin{tabular}{lcccccc}
\hline \multicolumn{1}{c}{$\begin{array}{c}\text { Socio-economic } \\
\text { group }\end{array}$} & $\begin{array}{c}\text { Sample } \\
\text { size }\end{array}$ & Min. & Max. & Median & Mean & $\begin{array}{c}\text { Standard } \\
\text { deviation }\end{array}$ \\
\hline Employees & 18279 & 6.67 & 69047.65 & 2336.28 & 2646.76 & 1661.10 \\
Farmers & 1509 & 6.72 & 105846.64 & 1862.00 & 2745.14 & 4083.79 \\
Self-employed & 2445 & 13.34 & 37296.77 & 2729.43 & 3348.28 & 2527.94 \\
Retirees and pensioners & 13101 & 1.77 & 15556.35 & 1839.00 & 2010.19 & 946.47 \\
Non-earned sources & 1526 & 23.09 & 20859.65 & 1212.00 & 1463.40 & 1286.08 \\
Total & 36860 & 1.77 & 105846.64 & 2097.68 & 2425.31 & 1731.37 \\
\hline
\end{tabular}

Source: own calculations.

Table 2

Estimates of income inequality, poverty and wealth indicators by socio-economic group

\begin{tabular}{|c|c|c|c|c|c|c|c|c|}
\hline $\begin{array}{l}\text { Socio-economic } \\
\text { spofeczno- } \\
\text { group }\end{array}$ & $\widehat{G}$ & $\hat{E}$ & $\widehat{W}_{p}$ & $\widehat{P G}$ & $\widehat{P G}_{p}$ & $\widehat{P S}_{p}$ & $\widehat{W}_{r}$ & $\widehat{R G}_{r}$ \\
\hline $\begin{array}{l}\text { ekonomiczna } \\
\text { Employees }\end{array}$ & 0.245 & 19.468 & 0.100 & 0.022 & 0.219 & 0.086 & 0.024 & 0.451 \\
\hline Farmers & 0.460 & 33.880 & 0.294 & 0.120 & 0.408 & 0.237 & 0.077 & 0.848 \\
\hline Self-employed & 0.296 & 22.609 & 0.065 & 0.016 & 0.245 & 0.110 & 0.075 & 0.039 \\
\hline $\begin{array}{l}\text { Retirees and } \\
\text { pensioners }\end{array}$ & 0.215 & 16.888 & 0.184 & 0.038 & 0.204 & 0.066 & 0.004 & 0.254 \\
\hline Non-earned sources & 0.306 & 24.171 & 0.527 & 0.188 & 0.356 & 0.181 & 0.012 & 0.558 \\
\hline Total & 0.266 & 20.785 & 0.153 & 0.038 & 0.248 & 0.103 & 0.022 & 0.515 \\
\hline
\end{tabular}

Source: own calculations.

Analysing the results presented in Table 1, there is a significant discrepancy between the mean and median income of farmers' households. The mean income is definitely higher, which indicates a strong positive asymmetry of the distribution caused by the occurrence of extremely high observations. The median income, being a more adequate measure of the average level of this phenomenon, shows that the group of farmers has income below the average observed for the whole country. It can also be noticed that farmers' households constitute the group with the highest income inequality among the five distinguished socio-economic groups. This is confirmed by the range (difference between the maximum and minimum household income) as well as the standard deviation. Inequality measures estimated in the study - the Gini index and the coefficient of maximum equalization - confirm that the farmers' households are a socio-economic group presenting the highest income inequality (Table 2). As much as $1 / 3$ of the total income of this group would 
have to be transferred from richer to poorer individuals so that the income would be equally distributed among all households $(\widehat{E}=33,88 \%)$. Households of farmers are also highly polarized - the percentage of poor households is high (29\%) and, at the same time, the percentage of farms considered rich is the highest $(7.7 \%)$. Additionally, the indices determining the poverty intensity and severity take the highest values. These findings emphasize the need to recognise differential effects of socio-economic status on income distribution and its inequality. Available incomes of the households of farmers in comparison to other socio-economic groups in Poland in 2003-2014 were also analysed in Grzelak (2016).

\section{Analysis of income distribution of a group of farmers by macro-region}

Income distributions of farmers' households were analysed according to six macro-regions of Poland: central, southern, eastern, north-western, south-western and northern. Individual regions are characterized by specific features that stimulate or inhibit the development of agriculture, which can obviously affects the income of farmers' households. In fact, farmers' households from the northern and north-western regions achieved the highest incomes (the means were equal to PLN 3147.58 and PLN 3084.99 respectively, and the corresponding median incomes were: PLN 1953.14 and PLN 2107.18), while the southern region was characterized by the lowest income (mean=PLN 2073.95, median=PLN 1566.24) which was definitely lower than for the entire socio-economic group of farmers. Such results are, above all, affected by natural and climatic conditions. Moreover, the highest dispersion of household income was also observed in the north-western region (standard deviation was PLN 5714.97). The sample sizes for particular regions, obtained after the division of the overall sample of 1509 farmers' households, were found too small to precisely estimate the Dagum model parameters.

Similarly to Table 2 , Table 3 presents the measures of income inequality, poverty and wealth, estimated for particular macro-regions, except for the coefficient of maximum equalisation, which was omitted due to insufficient sample sizes. In the south-western macro-region, there were no sampled households with incomes higher than the wealth threshold, which did not allow to determine the wealth index for this region.

In Figures 2-5 we can observe territorial differentiation of selected statistical characteristics of income distribution of farmers' households.

Figures 2 and 4 show that the poorest eastern and southern regions have the highest at-risk-of-poverty rates for farmers' households, equal to $39.8 \%$ and $35.9 \%$, respectively (Fig. 4). But the smallest percentage of poor households (22.9\%) was observed in the central region. The richest region from the point of view of the studied group turned out to be a highly polarized region of north-west. It is in this macro-region and in the northern macro-region that the highest percentage of households with incomes exceeding three times the median of equivalent income were observed (Fig. 5). In the south-western region, however, the poverty depth and poverty severity indexes were the highest and equaled $51 \%$ and $33.6 \%$, respectively (Table 3 ). This may result from significant differentiation within the group of households considered poor. 
Table 3

Estimates of income inequality, poverty and wealth indicators for farmers by macro-region

\begin{tabular}{lccccccc}
\hline \multicolumn{1}{c}{ Region } & $\widehat{G}$ & $\widehat{W}_{p}$ & $\widehat{P G}$ & $\widehat{P G}_{p}$ & $\widehat{P S}_{p}$ & $\widehat{W}_{r}$ & $\widehat{R G}_{r}$ \\
\hline Central & 0.416 & 0.229 & 0.093 & 0.405 & 0.221 & 0.078 & 0.603 \\
Southern & 0.393 & 0.398 & 0.137 & 0.344 & 0.171 & 0.038 & 0.434 \\
Eastern & 0.484 & 0.359 & 0.149 & 0.414 & 0.248 & 0.079 & 0.842 \\
North-western & 0.477 & 0.246 & 0.097 & 0.392 & 0.225 & 0.084 & 1.062 \\
South-western & 0.338 & 0.282 & 0.144 & 0.510 & 0.336 & - & - \\
Northern & 0.491 & 0.267 & 0.111 & 0.416 & 0.248 & 0.100 & 1.036 \\
Total & 0.460 & 0.294 & 0.120 & 0.408 & 0.237 & 0.077 & 0.842 \\
\hline
\end{tabular}

Source: own calculations.

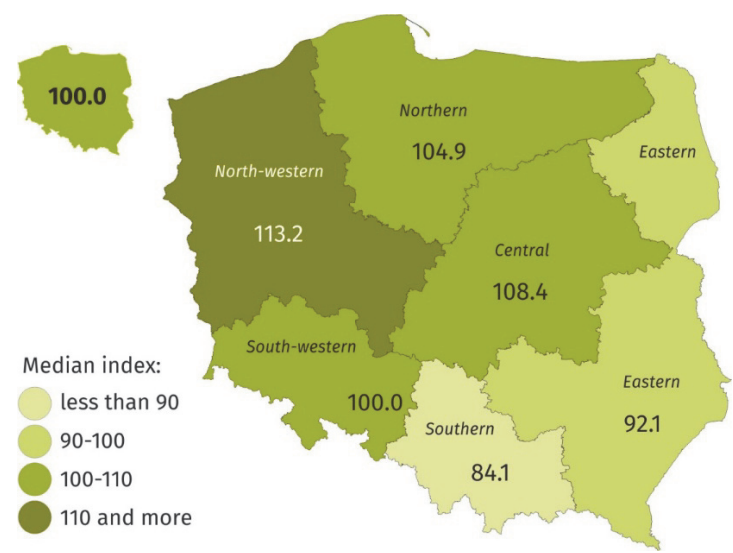

Fig. 2. Indicators of median income of farmers' households by macro-region in 2015 (Poland=100). Source: own elaboration.

The largest income inequalities measured by the Gini index were observed among the farmers' households in the northern (0.491), north-western $(0.477)$ and eastern (0.484) macro-regions (Fig. 3). The Gini index is higher there than the index for the group of farmers and definitely higher compared to the Gini index calculated for all Polish households (0.266). An interesting phenomenon is the overlapping of the areas with the largest inequalities, both with poor areas (the eastern region) and the richest ones (north-western region). This situation concerns to a certain extent also other groups of households and results partly from the specificity of the process of economic transformation in Poland. 


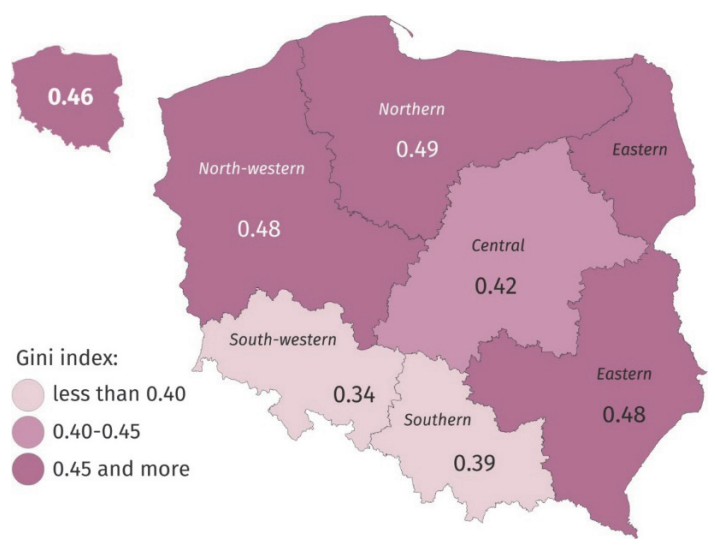

Fig. 3. Gini index for income distributions of farmers' households by macro-region in 2015. Source: own elaboration.

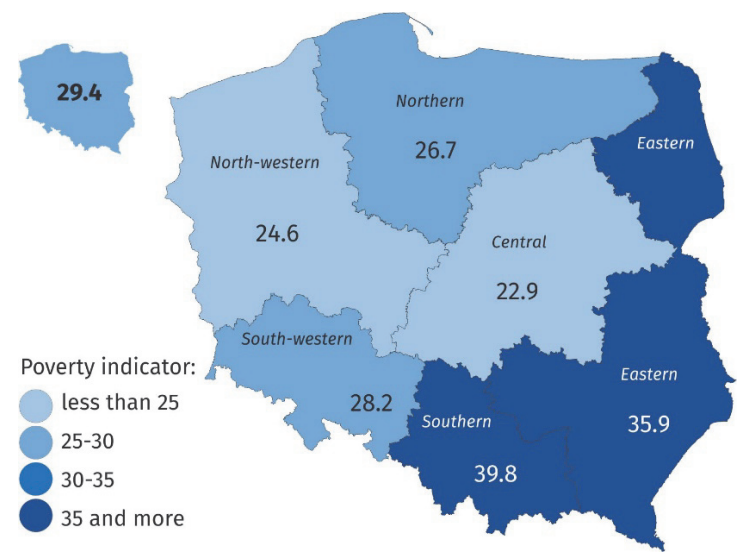

Fig. 4. At-risk-of-poverty rate for farmers' households by macro-region in 2015.

Source: own elaboration.

It should be noted that the northern macro-region is the area with the highest concentration of farmers' incomes and also the highest polarization of these incomes - households with extremely low income (below $60 \%$ median) or achieving very high income (over three times the median) make up almost $40 \%$ of the total population there. In turn, income distribution in the south-western region can be considered the most egalitarian - presenting the smallest Gini index, a small percentage of poor households and the lack of extremely high incomes. 


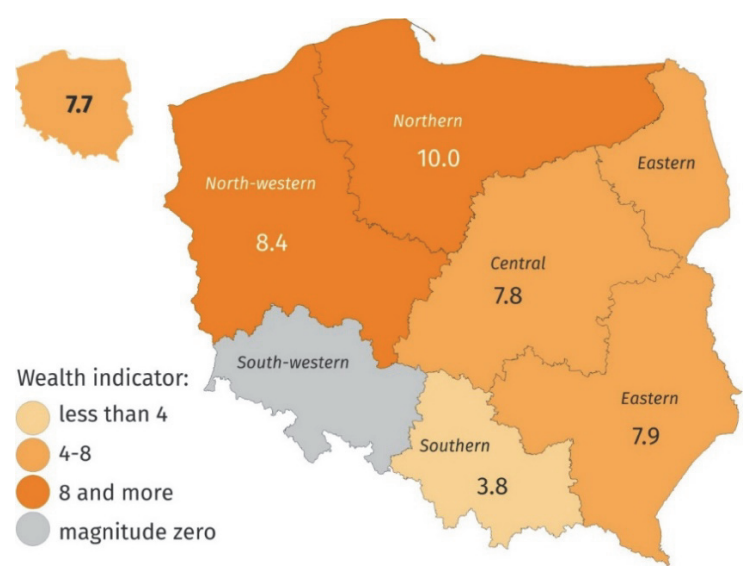

Fig. 5. Wealth index for farmers' households by macro-region in 2015.

Source: own elaboration.

\section{Conclusions}

The objective of the paper was to analyse the distribution of income of farmers' households in Poland in 2015. In particular, the levels of inequality, poverty and wealth have been taken into account.

Using a variety of statistical measures, the material situation of farmers' households with the situation of other socio-economic groups was compared. Against the background of other socio-economic groups, the group of farmers' households is characterized by a high level of average income, but at the same time the distribution of income observed in this group is highly concentrated. The result is, on the one hand, a very high percentage of people at risk of poverty and, on the other, a high percentage of very wealthy households.

Regional income inequality analysis revealed that the southern region is characterized by the lowest farmers' income, the highest percentage of households reaching income below the poverty line assumed as 0.6 median income of all households in Poland and a very low percentage of households with income above the value of three medians (and considered rich). It seems that in the north-western region the income situation of farmers' households is the best.

An interesting phenomenon is the overlapping of the areas with the largest inequalities, both with poor areas (the eastern region) and the richest ones (north-western region).

The application of the formulas incorporating sampling weights increased the accuracy of the estimates, but unfortunately sample sizes obtained for macro-regions within the Household Budget Survey may be too small to confirm reliable results when contrasting farmers' households in regions compared to the results obtained for other socio-economic groups. 
The analysis allowed to assess the risk of poverty and identify groups of most affluent households what can be helpful for social-policy makers focused on sustainable development. The problem of regional differentiation of farmers' households needs further research taking into account, e.g. types of agricultural activity carried out in particular macro-regions. 


\section{References}

Fei, J., Ranis, G., Kuo, S. (1978). Growth and the Family Distribution of Income by Factor Components. Quarterly Journal of Economics, no. 92, pp. 17-53.

Gini, C. (1912). Variabilita e Mutabilita. Tipografia di Pado Cuppini, Bolonia.

GUS (2016). Budżety gospodarstw domowych w 2015, ZWS. Retrieved from: http://stat.gov. pl/obszary-tematyczne/warunki-zycia/dochody-wydatki-i-warunki-zycia-ludnosci/budzety-gospodarstw-domowych-w-2015-r-,9,10.html.

Grzelak, M.M. (2016). Dochody rozporządzalne gospodarstw rolnych na tle innych grup społeczno-ekonomicznych w Polsce w latach 2003-2014. Annales Universitatis Mariae Curie-Skłodowska, sectio H, vol. 50, no. 4, pp. 139-149.

Jędrzejczak, A. (2011). Metody analizy rozkładów dochodów i ich koncentracji. Łódź: Wydawnictwo Uniwersytetu Łódzkiego.

Jędrzejczak, A., Pekasiewicz, D. (2017). Nierówności dochodowe gospodarstw domowych rolników na tle innych grup społeczno-ekonomicznych w Polsce w latach 2006-2014. Problemy Rolnictwa Światowego, volt. 17, no. 3, pp. 166-176.

Kopiński, J., Matyka, M. (2016). Ocena regionalnego zróżnicowania współzależności czynników przyrodniczych i organizacyjno-produkcyjnych w polskim rolnictwie. Zagadnienia Ekonomiki Rolnej, no. 1(346), pp. 57-79.

Kukuła, K. (red.) (2010). Statystyczne studium struktury agrarnej w Polsce. Warszawa: Wydawnictwo Naukowe PWN.

Kryszak, Ł. (2016). Nierówności dochodowe w rolnictwie krajów Unii Europejskiej w kontekście koncepcji zrównoważonego rozwoju. Roczniki Naukowe Stowarzyszenia Ekonomistów Rolnictwa i Agrobiznesu, no. 18(2), pp. 166-171.

Kot, S.M. (2008). Polaryzacja ekonomiczna. Teoria i zastosowanie. Warszawa: PWN.

Kleiber, C., Kotz, S. (2003). Statistical Size Distributions in Economics and Actuarial Sciences. Hoboken: Wiley.

Luty, L. (2016). Regionalne zróżnicowanie struktury obszarowej użytków rolnych w Polsce. Metody ilościowe w ekonomii, no. 17(1), pp. 62-71.

Marcysiak A., Marcysiak A. (2014). Zakres zróżnicowania poziomu dochodów z gospodarstwa rolnego w układzie regionalnym. Polityki europejskie, Finanse i Marketing, no. 12(61), pp. 122-128.

Michna, W. (2005). Zróżnicowanie funkcji gospodarstw rolnych w ujęciu przestrzennym. Program Wieloletni 2005-2009, no. 9. Warszawa: IERiGŻ-PIB. Retrieved from: www.ierigz.waw.pl/download/1142-9.pdf (access date: 1.07.2017).

Rusnak, Z. (2011). Pomiar ubóstwa i wykluczenia społecznego - problemy metodologiczne. Zeszyty Naukowe Wyższej Szkoły Bankowej we Wrocławiu, no. 20, pp. 387-408.

Panek, T. (2011). Ubóstwo, wykluczenie społeczne i nierówności. Teoria i praktyka pomiaru. Warszawa: Oficyna Wydawnicza SGH.

Sen,A. (1976). Poverty and Ordinal Approach to Measurement. Econometrica, no. 44, pp. 219-231.

Silber, J. (ed.). (1999). Handbook of Income Inequality Measurement. Boston: Kluwer Academic Publisher.

Średzińska, J. (2017).Zróżnicowanie poziomu dochodów rolników w gospodarstwach o różnych typach rolniczych w krajach Unii Europejskiej, Finanse. Rynki Finansowe, Ubezpieczenia, no. 5(89), pp. 145-155.

Wołoszyn, A., Wysocki, F. (2014). Nierówności w rozkładzie dochodów i wydatków gospodarstw domowych rolników w Polsce. Roczniki Naukowe SERiA, vol. XVI, issue 6, pp. 534-540. 
Zegar, J.S. (2008). Dochody $w$ rolnictwie $w$ okresie transformacji i integracji europejskiej. Warszawa: IERiGŻ-PIB.

Zenga, M. (1990). Concentration Curves and Concentration Indices Derived from Them. In: Income and Wealth Distribution, Inequality and Poverty (pp. 94-110). Berlin: Springer- Verlag Berlin Heidelberg.

Zenga, M. (2007). Inequality Curve and Inequality Index Based on the Ratios Between Lower and Upper Arithmetic Means. Statistica \& Applicazioni, vol. (1), pp. 3-27. 


\title{
ZRÓŻNICOWANIE ROZKŁADÓW DOCHODÓW GOSPODARSTW DOMOWYCH ROLNIKÓW W POLSCE WEDŁUG REGIONÓW
}

\begin{abstract}
Abstrakt
Badania dochodów gospodarstw domowych sa istotne zarówno z punktu widzenia analiz zmian $w$ czasie, jak $i$ porównań rozkładów $w$ różnych regionach geograficznych, grupach społecznych czy typach gospodarstw. W pracy przedstawione sq wyniki badań rozkładów dochodów w grupie gospodarstw domowych rolników $w$ makroregionach $w$ Polsce. Pozwalaja one sformułować wnioski dotyczace wielkości dochodów, ich nierównomierności, poziomu ubóstwa czy bogactwa w poszczególnych regionach oraz dokonać analizy porównawczej. Do analiz wykorzystano miary statystyczne takie jak indeks Giniego $i$ wskaźnik maksymalnego wyrównania oraz wybrane miary ubóstwa i bogactwa. Miary te oszacowano na podstawie danych indywidualnych pochodzacych z badania budzetów gospodarstw domowych w roku 2015 prowadzonego przez Główny Urzą Statystyczny. Wyniki badań wykazały, że największym zróżnicowaniem dochodów charakteryzuja się gospodarstwa domowe rolników regionu północnego. Jednocześnie w tym regionie zaobserwowano najwyższy odsetek gospodarstw uznawanych za zamożne. Najniższy współczynnik nierówności Giniego wystepuje natomiast w regionie południowo-zachodnim, w którym nie zaobserwowano gospodarstw o dochodach wyższych niż granica bogactwa.
\end{abstract}

Słowa kluczowe: gospodarstwo domowe rolników, region, nierówności dochodowe, ubóstwo, bogactwo.

Accepted for print: 5.09.2018.

Unless stated otherwise all the materials on the website are available under the Creative Commons Attribution 4.0 International license.

Some rights reserved to the Institute of Agricultural and Food Economics - National Research Institute.

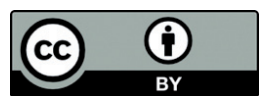

